\title{
Cultural Implications for the Shadow Economy
}

\author{
Andrzej Tomasz Buszko
}

University of Warmia and Mazury in Olsztyn

10-900 Olsztyn, Oczapowskiego 2 str., Poland

E-mail.buszko@uwm.edu.pl

cross $^{\text {ref }}$ http://dx.doi.org/10.5755/j01.ee.29.1.18069

The purpose of this paper is to recognize the correlation among dimensions of national culture and the shadow economy. Shadow economy exists in any country and it is fostering economic development. That is why not only academics but also researchers try to identify the factors affecting the shadow economy level. In literature and research studies relatively insignificant attention is paid to the relation between national culture and shadow economy. In order to identify the relation, the correlation analysis and Hofstede's categorized national culture dimensions were used. Shadow Economy (as a percentage of the official GDP) was calculated based on the DYMIMIC and the Currency Demand Method. The Pearson's coefficient index, and $t$-student test were used, as well. The correlation analysis revealed the correlation between the shadow economy and the following: the dimensions of national cultural power distance, uncertainty avoidance, and individualism vs. collectivism. There is a slight correlation between the shadow economy and masculinity vs. femininity. This is a novel empirical analysis of the shadow economy existing among the dimensions of national culture. Based on the achieved results there is a requirement to shape national culture. Thanks to that the level of shadow economy might be reduced. The unexpected findings of high correlation between some national cultural dimensions suggest the need for more research in this area.

Keywords: National Culture; Cultural Dimensions; Relationship; Shadow Economy; Roots; Effect of the Shadow Economy.

\section{Introduction}

Shadow economy is a phenomenon in the modern economy. It can be found in every single country. Shadow economy varies in terms of size and form of existence. It is difficult to explain the mechanism of legal activity without a basic knowledge of the shadow economy. In some countries shadow economy amounts to $50 \%$ of GDP (Schneider, 2007). Shadow economy is under continuous development. It is sometimes one-step below legal activity, sometimes functioning in parallel and is quite often a step ahead. This is due to changes in shadow economy. Well educated people with a good background in business activity, often manage their activities in the framework of shadow economy. Unfortunately, there is no one unified definition of shadow economy. In the literature one can find many classifications such as: illegal activity, non-reported, underground, black market, black zone, grey activity, informal economy, undeclared activity, not registered and so on. The European Union more often refers to the "undeclared economy" than to shadow economy. Different definitions mean different economic categories and this influences not only the meaning but refers to the size of it as well. This is because different tools are applied in order to measure the level of shadow economy. Additionally, it has a different impact on the economy. That is why some academic research states that shadow economy is neutral, while other works says that the impact is relatively small. However, there are some studies which show the positive impact of shadow economy on official growth. Adam and Ginsburg based their investigation on the case of Belgium and remarked that the growth of shadow economy (due to low entry costs) has a positive impact on GDP development (Adam \& Ginsburg, 1985). Generally, it is assumed that shadow economy has a negative impact on legal activity (Dreher \& Schneider, 2010). One commonly used working definition is: all economic activities that contribute to the officially calculated (or observed) gross national product but are currently unregistered (Schneider \& Enste, 2000). This approach is based on the taxonomy of underground economy originally proposed by Lippert and Walker (taking into account the type of activity - legal and illegal one, monetary and non-monetary transactions, tax evasion, tax avoidance) which is a narrow one (Lippert \& Walker, 1997). Katsios provides a specific definition of shadow economy, saying that the "shadow economy" consists of criminal activity, such as drug sales, smuggling, prostitution, bookmaking, gambling and other unlawful enterprises, as well as otherwise legal transactions that are mainly conducted in cash and unreported to fiscal or other competent authorities; this part of shadow economy is also known as the "parallel economy" (Katsios, 2006). Shadow economy requires a wider perspective. Shadow economy is (as such) an illegal activity which affects economic development. The most important causes for the increase in shadow economy are the rise of taxes and social security burdens. The bigger the difference between the total cost of labor in the official economy and after-tax earnings (from work), the greater the incentive to avoid this difference and to work in shadow economy (Schneider \& Enste, 2000). The most dangerous effects are related to corruption, negative levels of innovation and creativity, decreased competitiveness on the macro- and micro-level, as well as decreased budget revenues, which defunds education and 
reduces the quality of state institutions (Buehn, Lessmann, Markwardt, 2013). Luckily, there is active research being conducted in order to estimate the effects of shadow economy and its roots. Whenever the roots are known, it is easier to minimize the shadow economy activity. Generally, the most typical roots are as follows:

$$
\text { high level of taxes, }
$$

corruption,

organized crime,

inefficient government activity,

a complicated and contra-indicated legal system.

Whenever entrepreneurs face a high level of taxes, they try to hide some activity and avoid paying taxes. In such cases, some activity is transparent. Taxes are paid, but on the other hand some portion of the activity is illegal and this activity is not under taxation. A typical example is from the Polish construction sector. Some workers are hired without any agreement. They are paid, but any taxes from this activity are not collected. All transactions are done in cash. This is done with contracts as well. Corruption is always regarded as being dangerous for any national economy, especially when this practice involves politicians, government officials, businessmen, lawyers, police, and/or journalists. Such a mix of contacts dramatically changes the business environment and pushes it extremely quickly to shadow economy. Organized crime, together with economic crime, corruption and terrorism are serious forms of crime. Some researchers do not want to include organized crime into shadow economy. However, organized crime threatens individual areas of the social system. Traditionally, typical activities have been: production, smuggling and distribution of drugs, prostitution and trafficking of women, corruption, blackmail, fees "for protection", human trafficking, burglary, illegal migration, robbery, auto-theft, theft of jewelry and precious stones, computer crime, money laundering, counterfeiting of trade-marks, tax and credit collection, extortion of money, insurance and exchange fraud, handling stolen goods, illicit gambling, illegal import and export of toxic waste, international trade in arms and so on. Those activities are typical of organized crime. Some experts are not so willing to categorize it into shadow activity. They simply call it crime movement or black economy. With reference to the proposed new definition, such activity is illegal and affects economic development. Regardless, these operations are not legal ones, so from a methodological approach, they may be classified as shadow economy. Whenever organized crime is functioning at a higher level, it has a negative impact on legal business. Some entrepreneurs do not want to have any contacts with organized crime, because sooner or later their activity may be transferred to shadow economy. For example, as a consequence of money extortion / protection - this being the beginning of such contacts - all legal activity can eventually be taken over by mobsters (Buszko, 2016).

Generally, all countries try to minimize the level of shadow economy but this task seems to be quite difficult. The level of shadow economy consistently remains more or less the same. In developed countries, which are market oriented with democratic systems, the level of shadow economy is less than $10 \%$ of GDP. Countries under transition may have it as high as $30 \%$ of GDP, while less developed countries with economic or political problems may have shadow economy at a quite high level, even exceeding $50 \%$ of GDP (Schneider, 2008). These countries vary in many ways, and have different characteristics, such as their national culture.

\section{National Culture - a Review of the Literature}

In several seminal studies on national culture, there are underlying theses that national culture influences not only the work beliefs, norms, ethics and morality, but also the general business attitude (Hofstede, 1991, 2001; Inglehart et al., 1998; Trompenaars, 1994; Andersen et al., 2007; Black \& Mendenhall, 1989; Fang, 2003). National culture determines management behavior. In other words, national culture shapes organizational culture. Bhaskaran and Sukumaran found that significant cultural differences are evident across organizations owned and managed by individuals of one nationality and significant cultural similarities are evident across organizations owned and managed by individuals of different nationalities (Bhaskaran \& Sukumaran, 2007). Organizational culture has received a great deal of attention. The literature suggests that organizational culture can be a set of unique assets within a company. One should take into consideration the fact that national culture is a significant factor of a company's environment. Of course, many organizational cultures can exist in the same national culture frame. Whenever we would like to take shadow economy into account, it will be in the same national culture. Some companies accept shadow economy activity, but at the same time there are some companies that reject this category and even do not cooperate with such entities. Based on such attitudes, one can state that a dysfunctional organization may be based upon a dysfunctional national culture. Additionally, a dysfunctional organization causes many other problems that are not directly related to shadow economy, but to safety operations as well. For example, during the Columbia space shuttle disaster, there were people inside NASA who were discussing critical information with each other, but not with senior decision makers (Balthazard et al., 2006). Another very important issue related to organizational culture comes out whenever transnational mergers, acquisitions and collaborations occur. If the organizational culture and national culture are not taken into account, quite often the precious assets of the new entity can be lost. This is what happened when Daimler and Chrysler merged. The management failed to anticipate the scale of the tensions (Holden, 2002). Bonthous found out that a fundamental reason for business failures is inadequate information about the business environment and a lack of understanding of foreign cultures (Bonthous, 1994). Some scholars who study national culture have found several trends that lead to the success of a country. They provide the example of Singapore as evidence, and give the core factors fostering this city state's development (Haley \& Low, 1998). The government of Singapore is a highly efficient, honest and flexible meritocracy with a strong focus on integrated strategic planning and detailed execution (Lee et al., 2008). Economic development is a priority, and the state is distinguished by the absolute prioritizing of economic growth and its use as a prime indicator of the government's performance. Singaporean culture reflects values that serve 
Singapore in the long run. Faced with threats from the aggressive culture of the West, Singaporean culture reflects countervailing values that are helpful to Singapore (Kong, 2000). For centuries, Polish national identity has been built on Polish cultural heritage. Cultural heritage in national cultures conditions lives of generations through inherited traditions, stereotypes, and education in families, lifestyle, and in communication (Kowalska, 2012). This national identity helped gain the independence and quite successfully transferred economy from centrally planned to market oriented one. Referring to Ijose and Iossifova's research, the Czech and USA national cultures play an important role in understanding the diffusion and adoption of organizational practices. Moreover, they found out that the process of successfully diffusing recognition could happen since employees brought their cultural values and norms with them, even in the face of profound political and economic changes (Ijose, Iossifova, 2012). In Nordic countries, national culture significantly shapes business, which is entirely reliant on human resources. National culture focuses on law and ethical standards, practical attitude, education and social support (Whitmore, 2005). Because of that, human resources in the Nordic countries are well educated, feeling safe and willing to work hard for companies. The result of that is the Nordic model of economy - an innovative and effective one. In this way the space for shadow economy is limited.

Culture can be regarded as an important factor fostering development, but it can be a barrier. Myrdal argued that Indian culture based upon the caste system and religion froze citizen activity. This is the basic root of Indian poverty. The same Indian citizens who have transferred to Great Britain, the USA, or even to Africa have become successful businessmen or helpful clerks in British administrations (Myrdal, 1971).

The roots of cultural understanding are associated with the sociological work of Max Weber. Culture is commonly understood in Weberian sociology as the shared set of beliefs that influence what we consider to be meaningful and valuable. Disciplines, professions, and institutions in modern bureaucratic society nurture and transmit cultural values and meanings. A very popular concept called the theory of transaction cost provides insight into cultural influences on organizational structure. Later, cultural issues were added to this theory, which affects:

- codification: the degree of formal representation;

- diffusion: the degree of codification that has spread throughout the population (Harvey, 1997).

The first authors who studied national culture through certain dimensions were Kluckhohn and Strodtbeck (1961). They created six basic fundamental questions, and provided for them three possible answers, which could serve to characterize national cultures. The proposed questions were related to: human nature, relationship with nature, nature of human activity, cooperation vs. individualism, time orientation and space origin. G. Hofstede's work, which includes four dimensions of national culture: power distance, uncertainty avoidance, individualism vs. collectivism, and masculinity vs. femininity, has gained the widest recognition, and includes. Hofstede's study included 117,000 employees from the company IBM, who were employed in more than 60 countries. Later on, two other dimensions were added: long- term orientation and indulgence vs. restraint (Hofstede, 1980). Hofstede's conceptualization of culture is both theoretically and empirically criticized. However, according to Google Scholar, the first edition of Hofstede's book has been cited more than 26,000 times and the second one - more than 21,000 times (McSweeney, Brown \& Iliopoulou, 2016). The criticism ranges from qualms about the epistemological assumptions of his work and questions about the soundness of the methodology and interpretation of the data, to unease with his conceptualization of culture and the associated value dimensions (Touburg, 2016). Ritzer's idea of McDonaldization is in a way valid (Ritzer, 2011). Randlesome raised the unification of Europe as a threat to culture. In fact, she focused on business culture, but it could have a sound impact on national culture as well (Randlesome, 2002). On the other hand, Hofstede's conceptualization is a pioneering work on national culture. Hofstede distinguished between nations and societies, and pointed out that there was a difference among cultures, especially when it was related to values. Kuipers has developed Hofstede's idea and introduced the term of "national habit". This consists of learned practices and norms of behavior (Kuipers, 2013).

The GLOBE study (Global Leadership and Organisational Behaviour Effectiveness) identified nine dimensions of national culture. The general idea of this study is based on Hofstede's methodology. Within this study, the following dimensions were recognized: power distance, uncertainty avoidance, human orientation, institutional collectivism, intragroup collectivism, determination, gender equality, orientation towards the future, and focus on performance (House et al., 2004). Trompenaars and Hampden-Turner worked for more than 10 years on the dimensions of national culture. They specified seven dimensions: internal direction vs. outer direction, time orientation, achievement vs. ascription, neutralism vs. emotionalism, individualism vs. communitarianism, universalism vs. particularism, specific vs. diffuse (Trompenaars \& Hampden-Turner, 1997). According to Ghemawat and Reiche (2011), in the most recent approach to classification of cultures Gelfand and her research team distinguished 33 nations in terms of their tightness. According to authors, tight cultures such as Pakistani, Indian or Korean have many strong norms and a low tolerance for deviant behavior; whereas, loose cultures such as Ukrainian, Hungarian or the Dutch have weak social norms and a high tolerance for deviant behavior. Tight cultures afford a much smaller range of permissible behavior across everyday situations. "Given these higher situational constraints, individuals in tight cultures will focus on avoiding mistakes, behaving properly and will also tend to have higher selfregulatory strength (higher impulse control) and a greater need for structure" (Ghemawat \& Reiche, 2011, p.5).

\section{Methodological Approach}

Dimensions of national cultures were adopted from Hofstede's approach. The list of 30 selected countries is presented in table 1. Shadow Economy (as a percentage of the official GDP) was calculated based on the DYMIMIC and the Currency Demand Method, and it is also presented in the last column of table 1. The Pearson's coefficient index and t-student test were used. Results are presented in table 
2. Statistica software program was used for calculations. The following hypotheses were established:

$\mathrm{H} 1$ : There is a positive correlation between masculinity vs. femininity and the size of shadow economy

$\mathrm{H} 2$ : There is a negative correlation between uncertainty avoidance and the size of shadow economy
H3: There is a positive correlation between power distance and the size of shadow economy

H4: There is a positive correlation between individualism vs. collectivism and the size of shadow economy

Table 1

Hofstede's Cultural Value Scores for 30 Selected Countries and the Size of the Shadow Economy

\begin{tabular}{|c|c|c|c|c|c|}
\hline Country & Power distance & $\begin{array}{c}\text { Individualism vs } \\
\text { Collectivism }\end{array}$ & $\begin{array}{c}\text { Uncertainty } \\
\text { avoidance }\end{array}$ & $\begin{array}{c}\text { Masculinity vs } \\
\text { Femininity }\end{array}$ & $\begin{array}{c}\text { The size of the Shadow } \\
\text { Economy (\% GDP) }\end{array}$ \\
\hline Argentina & 49 & 46 & 86 & 56 & 25 \\
\hline Australia & 36 & 90 & 51 & 61 & 11 \\
\hline Brazil & 69 & 38 & 76 & 49 & 24 \\
\hline Canada & 39 & 80 & 48 & 52 & 9 \\
\hline Chile & 63 & 23 & 86 & 28 & 18 \\
\hline China & 80 & 20 & 30 & 66 & 16 \\
\hline Colombia & 67 & 13 & 80 & 64 & 28 \\
\hline Denmark & 18 & 74 & 23 & 16 & 7 \\
\hline France & 68 & 71 & 86 & 43 & 13 \\
\hline Germany & 35 & 67 & 65 & 66 & 11 \\
\hline Greece & 60 & 35 & 112 & 57 & 36 \\
\hline Indonesia & 78 & 14 & 48 & 46 & 19 \\
\hline India & 77 & 48 & 40 & 56 & 21 \\
\hline Iran & 58 & 41 & 59 & 43 & 20 \\
\hline Israel & 13 & 54 & 81 & 47 & 11 \\
\hline Italy & 50 & 76 & 75 & 70 & 25 \\
\hline Japan & 54 & 46 & 92 & 95 & 8 \\
\hline Korea South & 60 & 18 & 85 & 39 & 9 \\
\hline Malaysia & 104 & 26 & 36 & 50 & 12 \\
\hline Mexico & 81 & 30 & 82 & 69 & 28 \\
\hline Netherlands & 38 & 80 & 53 & 14 & 10 \\
\hline Philippines & 94 & 32 & 44 & 64 & 26 \\
\hline Poland & 68 & 60 & 93 & 64 & 25 \\
\hline Portugal & 63 & 27 & 104 & 31 & 24 \\
\hline Russia & 93 & 39 & 95 & 36 & 28 \\
\hline Singapore & 74 & 20 & 8 & 48 & 7 \\
\hline Spain & 57 & 51 & 86 & 42 & 22 \\
\hline Sweden & 31 & 71 & 29 & 5 & 9 \\
\hline Great Britain & 35 & 89 & 35 & 66 & 12 \\
\hline USA & 40 & 91 & 46 & 62 & 16 \\
\hline
\end{tabular}

Sources: Ghemawat P., \& Reiche S. (2011). National Cultural Differences and Multinational Business. Globalization Note Series, p. 12; Hofstede G., Culture's Consequences: International Differences in Work-Related Values, 1980, Beverly Hills, CA: Sage

\section{Empirical Findings}

Based on the methodological approach, empirical findings are presented in table 2.

Table 2

Correlation Results Among Shadow Economy and the Dimensions of National Culture (Hofstede's Approach)

\begin{tabular}{|l|c|c|c|c|}
\hline Category & Power distance & $\begin{array}{c}\text { Individualism vs. } \\
\text { Collectivism }\end{array}$ & $\begin{array}{c}\text { Uncertainty } \\
\text { avoidance }\end{array}$ & $\begin{array}{c}\text { Masculinity vs. } \\
\text { Femininity }\end{array}$ \\
\hline Power distance & 1 & -0.686070 & 0.085470 & 0.212781 \\
\hline $\begin{array}{l}\text { Individualism vs } \\
\text { Collectivism }\end{array}$ & -0.686070 & 1 & -0.20226 & -0.43484 \\
\hline $\begin{array}{l}\text { Uncertainty } \\
\text { avoidance }\end{array}$ & 0.085470 & -0.202226 & 1 & 0.471476 \\
\hline $\begin{array}{l}\text { Masculinity vs } \\
\text { Femininity }\end{array}$ & 0.212781 & -0.43484 & 0.161867 & -0.36669 \\
\hline Shadow Economy & 0.471476 & -0.36669 & $\underline{0.571165}$ & 0.571165 \\
\hline
\end{tabular}

$p<0.05$, t-student test source: own estimation

At first glance, these results are just a little bit unexpected. There is a strong positive correlation between shadow economy and uncertainty avoidance (0.571165), and quite strong correlations between shadow economy and power distance (0.471476), shadow economy and individualism vs. collectivism (-0.36669), masculinity vs. femininity and shadow economy (0.227667). Two hypotheses were confirmed $(\mathrm{H} 1, \mathrm{H} 3)$, but two others $(\mathrm{H} 2$, 
H4) were not confirmed. The correlation between shadow economy and uncertainty avoidance is positive, although a negative correlation value was expected. The correlation between shadow economy and individualism vs. collectivism is negative. The expected value was supposed to be positive.

Individualism vs. collectivism focuses on the relation between an individual and a group. In a country that Hofstede ranks high regarding individualism, the interests of an individual are more likely to prevail over the interests of the group. Conversely, in societies that score lower on Hofstede's individualism scale (and thus rank higher regarding collectivism), the general interests of the collective body prevail over those of an individual. Low scoring of uncertainty avoidance means that people are tolerant of risk and different or alternative options. They could be regarded as brave and entrepreneurial. High scoring refers to a situation where people fear embarrassment if they find themselves in an unusual situation. A high value of Power Distance (PDI) means authority is distributed unequally. A low level of PDI authoritative status is less well-defined and power is more decentralized. Furthermore, in a high PDI society the use of power to extort personal gains would be acceptable; while in a low PDI society, a similar extraction of private benefits would be detested. Additionally, greater degree of inequality is expected in a high PDI society a (D'Souza \& Nash, 2016). From the theoretical perspective, a more probable correlation would be between shadow economy and long-term versus shortterm orientation, especially in countries where national culture is characterized by shortterm orientation. People and entrepreneurs focus on the present and the near future. This means that they expect benefits as quickly as possible. This attitude might push them to shadow economy. The same story could be applicable to masculine values, which are associated with a strong tendency for achievement, awards and recognition as the main motivating factors of behavior. If achievement cannot be executed within the frame of legal activity, people can quite easily take a risk and go to shadow economy. The lowest rate of uncertainty avoidance is in Singapore (8), but the highest rate is in Greece (122). The size of the Greek underground economy reached immensely high levels between 1973 and 1979, that is at the end of the military dictatorship and shortly thereafter (Bitzenis \& Makedos, 2013). The Greek underground economy only started to fall after the transition to a new democratically elected regime had been completed, the new constitution had been approved and the uncertainty regarding the future political and economic course of the country had declined (Berger et al., 2014). A very important aspect in the case of Greece was corruption. Corruption in public administration (as measured, for example, by the Corruption Perception Index provided by Transparency International - CPI) was at quite a high level (46), which ranked this nation as $58^{\text {th }}$ among
168 countries in the world. Based on research studies on the relation between corruption and shadow economy, it is possible to reach the conclusion that the larger the shadow economy, the poorer the quality of institutions; especially in lower income countries (Friedman et al., 2000). Based on the literature, it is known that countries with high levels of shadow economy have comparatively high public debt. This is simply because shadow economy is not taxed with the same levies as the legal economy. Shadow economy entities pay some taxes or nothing (Prinz \& Beck, 2012), although workers from shadow economy spend ca. $60 \%$ of their wages legally, and VAT contributes to budget revenue (Schneider, 2000).

\section{Conclusions}

The main goal of research was achieved. There is a relation between national culture and shadow economy. National culture has proven not to be dysfunctional in reducing shadow economy. This is especially significant with respect to two dimensions of national culture: uncertainty avoidance and power distance. These dimensions require deeper studies. Individuals and firms active in shadow economy run the risk of being detected, convicted and punished. In such dimensions of national culture (connected with uncertainty avoidance), shadow economy is supposed to be quite high. However, the empirical results and discussion show that shadow economy in countries with such national culture is characterized as having a low level of shadow economy activity. Many academics, researchers even politician try to find out and introduce effective way to reduce the level of shadow economy. Weakness of such an approach lies in disregarding national culture. Taking national culture into account while attempting to reduce shadow economy seems to be necessary. This applies to the tendency of high-risk activity, as well. National culture affects business activity and result of it specific model of economy can be created. A good example is the Nordic model of economy. National culture supports business and reduces the level of shadow economy. This research raises some questions. The first one is associated with the definition of shadow economy. There are so many definitions, and different definitions make different economic categories. This affects measurement of shadow economy. Whenever a researcher fails to define shadow economy precisely, the measurement of it varies. National culture affects shadow economy at different levels and there is a dynamic relation between different layers of culture. Since national culture fosters shadow economy, it may reinforce domestic prosperity. What should also be taken into account is that Hofstede's national culture dimensions cannot be projected onto individuals. That is why some studies on national culture affecting individuals and organization are required. 


\section{References}

Adam, M. C., \& Ginsburgh, V. (1985). The Effects of Irregular Markets on Macroeconomic Policy: Some Estimates for Belgium. European Economic Review, 29(1), 15-33. https://doi.org/10.1016/0014-2921(85)90036-4

Andersen, T., M., Holmstrom, B., Honkapohja, S., Korkman, S., Soderstrom, H., T., \& Vartiainen, J. (2007). The Nordic Model. Embracing globalization and sharing risks. The Research Institute of the Finnish Economy (ETLA), Taloustieto Oy, 24-36

Balthazard, P. A., Cooke, R. A., \& Potter, R. E. (2006). Dysfunctional culture, dysfunctional organization Capturing the behavioral norms that form organizational culture and drive performance. Journal of Managerial Psychology. 21(8), 709-732. https://doi.org/10.1108/02683940610713253

Berger, W., Pickhardt, M., Pitsoulis, A., Prinz, A., \& Sarda, J. (2014). The hard shadow of the Greek economy: new estimates of the size of the underground economy and its fiscal impact. Applied Economics, 46(18), 2190-2204. https://doi.org/10.1080/00036846.2014.896984

Bhaskaran, S., \& Sukumaran, N. (2007). National culture, business culture and management practices: consequential relationships? Cross Cultural Management, 14(1), 54-67. https://doi.org/10.1108/13527600710718831

Bitzenis A., \& Makedos I. (2013). The absorption of a shadow economy in the Greek GDP. The Economies of Balkan and Eastern Europe Countries in the Changed World, 33-41

Black, J. S., \& Mendenhall, M. (1989). A practical but theory-based framework for selecting cross-cultural training methods., Human Resource Management, 28(4), 511-39. https://doi.org/10.1002/hrm.3930280406

Bonthous, J. M. (1994). Culture - the missing intelligence variable, The Strategic Planning News, March.

Buehn, A., Lessmann, Ch., \& Markwardt, G. (2013). Decentralization and the shadow economy: Oates meets AllinghamSandmo. Applied Economics, 45, 2567-2578. https://doi.org/10.1080/00036846.2012.671923

Cahyadi,G., Kursten, B., Weiss, M., \& Yang, G. (2004). Singapore's Economic Transformation, Global Urban Development Singapore Metropolitan Economic Strategy Report. Global Urban Development Prague, Czech Republic

Buszko, A. (2016). Mechanizmy szarej strefy. CeDeWu. Warszawa

Dreher, A., \& Schneider, F. (2010). Corruption and the shadow economy: an empirical analysis, Public Choice, 144, 21538. https://doi.org/10.1007/s11127-009-9513-0

D'Souza, J., \& Nash, R. (2016). Private Benefits of State Ownership: The Role of Media and National Culture. Journal of Accounting and Finance, 16(4), 97-114

Fang, T. (2003). A critique of Hofstede's fifth national culture dimension. Cross Cultural Management, 3(3), 347-68. https://doi.org/10.1177/1470595803003003006

Friedman, E., Johnson, S., \& Kaufmann, D. (2000). Dodging the grabbing hand: the determinants of unofficial activity in 69 countries, Journal of Public Economics, 76, 459-93. https://doi.org/10.1016/S0047-2727(99)00093-6

Ghemawat P., \& Reiche S. (2011). National Cultural Differences and Multinational Business. Globalization Note Series. Accessed through: https://www.ghemawat.com/wordpress/wp-content/uploads/2011/01/NationalCultu ralDifferences.pdf

Haley U.C.V., \& Low L., (1998). Crafted culture: governmental sculpting of modern Singapore and effects on business environments. Journal of Organizational Change Management, 11(6), 530-553. https://doi.org/10.1108/095 34819810242761

Harvey, F. (1997). National cultural differences in theory and practice Evaluating Hofstede's national cultural framework. Information Technology \& People, 10(2), 132-145. https://doi.org/10.1108/09593849710174986

Hofstede, G. (1980). Culture's Consequences: International Differences in Work-Related Values, Sage, Beverly Hills, CA

Hofstede, G. (1991). Cultures and Organizations: Software of the Mind, McGraw-Hill, NewYork, NY

Hofstede, G. (2001). Culture's Consequences: Comparing Values, Behaviors, Institutions and Organizations across Nations, Sage, Thousand Oaks, CA

Holden, N. J. (2002). Cross-Cultural Management: A Knowledge Management Perspective, Pearson Education, Harlow

House, R. J., Hanges, P. J., Javidan, M., Dorfman, P. W., \& Gupta, W. (2004). Culture, Leadership, and Organizations. The GLOBE Study of 62 Societies. Sage Publishing CA

Ijose, O., \& Iossifova, A. (2012). National culture and the adoption of organizational practices: evidence from a global company's call centers in two market economies, Journal of International Business and Cultural Studies, 6(1), 26-35

Inglehart, R., Basanez, M., \& Moreno, A. (1998). Human Values and Beliefs: A Cross-Cultural Sourcebook, University of Michigan Press, Ann Arbor, Michigan. https://doi.org/10.3998/mpub.14858 
International Science Bulletin, (1951). National Stereotypes and National Understanding. 3(3) Autumn.

Katsios, S. (2006). The Shadow Economy and Corruption in Greece. South-Eastern European Journal of Economics, 1, 61-80.

Kluckhohn, F. R., \& Strodtbeck, F. L (1961). Variations in value orientations. Evanston: Row, Peterson

Kong, L., (2000). Cultural policy in Singapore: Negotiating economic and socio-cultural agendas. Geoforum, 31, 409-411. https://doi.org/10.1016/S0016-7185(00)00006-3

Kowalska, S. (2012). Cultural Heritage in Poland - the Background, Opportunities and Dangers. UAM University. Poznań

Kuipers, G. M. M. (2013).The rise and decline of national habitus: Dutch cycling culture and the shaping of national similarity. European Journal of Social Theory, 16(1), 17-35. https://doi.org/10.1177/1368431012437482

Lippert, O., \& Walker M. (eds.) (1997). The Underground Economy: Global Evidences of its Size and Impact, Vancouver BC: Frazer Institute

Myrdal, G. J. (1971). Asian Drama: An Inquiry into the Poverty of Nations, New York: Pantheon, 39-50

McSweeney, B., Brown, D., Iliopoulou, S. (2016). Claiming Too Much, Delivering Too Little: Testing Some of Hofstede's Generalisations. Irish Journal of Management, 35(1), 34-57. https://doi.org/10.1515/ijm-2016-0003

Lee, S. K., et al. (eds) (2008). Toward a Better Future: Education and Training for Economic Development in Singapore since 1965, The World Bank Publications, Washington. https://doi.org/10.1596/978-0-8213-7375-0

Prinz, A.,Beck, H. (2012). In the shadow of public debt: are there relations between public debt and the shadow economy? Economic Analysis and Policy, 42, 221-36. https://doi.org/10.1016/S0313-5926(12)50022-6

Randlesome, C. (2002). Diversity of Europe's Business Cultures Under Threat? Cross Cultural Management: An International Journal, 9(2), 65-73. https://doi.org/10.1108/13527600210797406

Ritzer, G. (2011). The McDonaldization of Society, 6th ed., Pine Forge Press, Thousand Oaks, CA, London and New Delhi

Schneider, F. (2008). Shadow Economies and Corruption all over the World: Empirical Results for 1999 to 2003. In special issue of the International Journal of Social Economics (IJSE), 35(9), 4.

Schneider, F. (2007). Shadow economies and corruption all over the World: new estimates for 145 countries. OpenAssessment E-Journal, 1, 1-66

Schneider F., \& Enste D. (2000). Shadow Economies: Size, Causes, and Consequences. Journal of Economic Literature Vol. XXXVIII, March, 77-114. https://doi.org/10.1257/jel.38.1.77

Trompenaars, F., \& Hampden-Turner, C. (1997). Riding the Waves of Culture: Understanding Cultural Diversity in Business (2nd ed). London: Nicholas Brealey

Touburg, G. (2016). National habitus: an antidote to the resilience of Hofstede's "national culture"? Journal of Organizational Change Management, 29 (1), 81-92. https://doi.org/10.1108/JOCM-11-2015-0219

Whitmore, J. (2005). Business Class: Etiquette Essentials for Success at Work, St. Martin's Press

The article has been reviewed.

Received in April, 2017; accepted in February, 2018. 